\title{
CLA induced milk fat depression reduced dry matter intake and improved energy balance in dairy goats
}

\author{
M. Baldin ${ }^{a}$, R. Dresch ${ }^{a}$, J. Souza ${ }^{b}$, D. Fernandes ${ }^{a}$, M.A.S. Gama ${ }^{\text {, }}$ \\ K.J. Harvatine ${ }^{\mathrm{d}}$, D.E. Oliveira ${ }^{\mathrm{a}, *}$ \\ a Department of Animal Production, Santa Catarina State University, Lages, Santa Catarina 88520-000, Brazil \\ b Department of Animal Science, University of Sao Paulo, ESALQ, Piracicaba, Sao Paulo 13418-000, Brazil \\ c Embrapa Dairy Cattle, Juiz de Fora, Minas Gerais 36038-300, Brazil \\ ' Department of Dairy \&'Animal Science, Penn State University, University Park, State College, PA 16802, USA
}

\section{A R T I C L E I N F O}

\section{Article history:}

Received 16 July 2013

Received in revised form

29 September 2013

Accepted 2 October 2013

Available online 16 October 2013

\section{Keywords:}

Conjugated linoleic acid

Toggenburg goats

Methyl ester

Rumen biohydrogenation

\begin{abstract}
A B S T R A C T
The extent to which CLA supplements inhibit milk fat synthesis is highly dependent on the amount of trans-10, cis-12 CLA reaching the mammary gland. Secondary events such as changes in milk yield, dry matter intake (DMI), body weight (BW) and energy balance (EB) may also occur depending on the magnitude of milk fat depression. This study investigated the effects of feeding a rumen unprotected CLA methyl ester supplement on milk fat yield and fatty acid (FA) profile, yield of milk and other milk components, DMI and metabolic variables in dairy goats. Twenty primiparous, non-pregnant Toggenburg goats, paired by BW, days in milk (DIM) and milk yield (MY) $[2.8 \pm 0.4$ (mean \pm SEM) $\mathrm{kg}$ milk/day, BW of $40 \pm 3.7 \mathrm{~kg}$ and $75 \pm 3$ days in milk] were used in a crossover design with 14 days treatment periods and a 6 days washout. Goats were randomly assigned to the following treatments: Control ( $30 \mathrm{~g} /$ day of calcium salts of FA) or CLA [ $30 \mathrm{~g} /$ day of a rumen unprotected CLA methyl ester supplement (29.9\% trans-10, cis-12 CLA)]. There was no treatment effect on BW, milk yield, or milk protein and lactose content and yield. However, compared to Control, CLA decreased milk fat content and yield by 13.9 and $13.3 \%$, respectively, and CLA treated goats consumed $6.5 \%$ less corn silage. The CLA treatment increased the concentration of both CLA isomers (cis-9, trans-11 and trans-10, cis-12) in milk fat. The concentration of short and medium chain milk FA (C16) was decreased by CLA, while long chain FA were increased. However, the daily secretion was lower for FA of all chain lengths in CLA treated goats. Glucose and insulin were not affected by treatment, while CLA treatment decreased non esterified FA by $22.2 \%$. The CLA treatment improved calculated EB by $0.3 \mathrm{Mcal} /$ day. Overall, CLA methyl ester supplements are effective in causing milk fat depression in lactating dairy goats and improving EB, which may be used as a nutritional tool in some circumstances.
\end{abstract}

(c) 2013 Elsevier B.V. All rights reserved.

\section{Introduction}

The trans-10, cis-12 CLA isomer was identified as a bioactive fatty acid (FA) capable of causing milk fat

\footnotetext{
* Corresponding author. Tel.: +55 4933224202 .

E-mail addresses: dimas.oliveira@udesc.br, dimaseoliveira@gmail.com (D.E. Oliveira).
}

depression (MFD) in dairy cows (Baumgard et al., 2000). Thereafter, its effects have been well characterized including the establishment of dose-response relationships for dairy cows (De Veth et al., 2004) and elucidation of partial mechanisms of its specific inhibition of mammary lipid synthesis (Baumgard et al., 2002; Harvatine and Bauman, 2006). Recently, trans-10, cis-12 CLA inhibition of lipid synthesis has been documented in lactating sheep (Oliveira et al., 2012) and goats (Baldin et al., 2013). 
Controlled induction of MFD is a possible nutritional tool with potential applications on dairy farms, therefore CLA induced MFD continues to be an active research area. Under certain dietary conditions, MFD may result in increased milk and/or milk component yield (Medeiros et al., 2010) or improvement in energy balance and milk yield (Odens et al., 2007). The effectiveness in which a dietary CLA supplement causes MFD is related to the extent in which its metabolism by rumen bacteria is prevented. Thus, the majority of CLA studies have used post-ruminal infusion or rumen-protected CLA supplements (e.g. calcium salts, amide linkages, formaldehyde treatment and lipid encapsulation). As reviewed by Moon et al. (2008), the extent of protection from rumen bacteria as well as post-ruminal bioavailability varies among these supplements, becoming an important issue due to the variation in manufacturing processes and costs associated with their production.

Feeding unprotected CLA methyl ester provides a simple, convenient and lower cost method for supplementation. Dohme-Meier and Bee (2012) showed that feeding an unprotected CLA supplement as methyl ester were able to reduce milk fat synthesis in dairy cows and Baldin et al. (2013) showed in goats fed a total mixed ratio (TMR) diet. Nevertheless, studies using small ruminants are still scarce and the extent of biohydrogenation and the effectiveness of MFD induction are unclear. Thus, the objective of this study was to investigate the effects of feeding a rumen unprotected CLA methyl ester supplement mixed to concentrate on dairy goats milk fat yield and fatty acid profile as well as yield of milk and other milk components, dry matter intake (DMI), energy balance (EB) and key plasma metabolites and metabolic hormones.

\section{Materials and methods}

\subsection{Design and management}

The Santa Catarina State University Ethical Committee approved all experimental procedures. Twenty primiparous, non-pregnant Toggenburg goats with milk yield $2.8 \pm 0.4$ (mean \pm SEM) $\mathrm{kg} /$ day, BW of $40 \pm 3.7 \mathrm{~kg}$ and $75 \pm 3$ days in milk were housed in pairs in pen with free access to mineral salt and water. Goats were milked by hand twice a day at 0500 and $1600 \mathrm{~h}$, and monitored throughout the experiment for the presence of mastitis using the California Mastitis Test.

Goats received $0.9 \mathrm{~kg} /$ day (dry matter, DM) of a concentrate containing ground corn (51.3\%), soybean meal (38.5\%), cottonseed meal (5.1\%), limestone $39 \% \mathrm{Ca}(1.3 \%)$ and a commercial vitamin-mineral mix (3.8\%). This concentrate was individually fed after morning and afternoon milkings $(0.45 \mathrm{~kg} / \mathrm{meal})$. Briefly, the procedure to assure individual intake consisted of tying goats (using a chain attached to the neck collar) to one of each pen corner. After complete consumption of the concentrate, goats were untied and corn silage was weighed and fed ad libitum. Silage orts were weighed and recorded for each pen before each concentrate feeding. The diet was formulated using the Small Ruminant Nutrition System (Tedeschi et al., 2010) to meet NRC (2007) nutrient requirements. Chemical composition of the corn silage and concentrate is presented in Table 1.

A crossover design with 14 days treatment periods and 6 days washout interval was used. Animals were paired by BW, DIM and MY and randomly assigned to the following treatments: Control - $30 \mathrm{~g} /$ day of calcium salts of FA (Megalac-E, Church \& Dwight Co., Nova Ponte, Brazil) or CLA - 30 g/day of a rumen unprotected CLA supplement (Luta-CLA 60, BASF AG, São Paulo, Brazil). Fatty acids in the CLA supplement were in the form of methyl esters and trans-10, cis-12 CLA accounted for $29.9 \%$ of total FA (Table 2). Calcium salts of FA were fed as a control treatment so that diets were isoenergetic.
Table 1

Chemical composition of experimental corn silage and concentrate.

\begin{tabular}{lcc}
\hline Chemical & Silage & Concentrate \\
\hline DM, \% & 26.7 & 90.1 \\
CP, \% of DM & 6.7 & 25.1 \\
EE, \% of DM & 1.4 & 3.1 \\
NDF, \% of DM & 58.3 & 11.9 \\
ADF, \% of DM & 32.6 & 6.7 \\
Lignin, \% of DM & 4.1 & 3.1 \\
ME, Mcal/kg of DM & 2.4 & 2.9
\end{tabular}

DM: dry matter; EE: ether extract; ME: metabolizable energy.

a Calculated according NRC (2007).

Table 2

Fatty acid composition of lipid supplements.

\begin{tabular}{|c|c|c|}
\hline \multirow{2}{*}{$\begin{array}{l}\text { Fatty acids } \\
\text { (g/100 g of total fatty acids) }\end{array}$} & \multicolumn{2}{|c|}{ Supplement ${ }^{\mathrm{a}}$} \\
\hline & Control & CLA \\
\hline $\mathrm{C} 4: 0$ to $\mathrm{C} 11: 0$ & 0.67 & nd \\
\hline $\mathrm{C} 12: 0$ & 2.85 & nd \\
\hline C14:0 & 1.12 & nd \\
\hline C14:1 cis-9 & 0.01 & nd \\
\hline C15:0 & 0.06 & nd \\
\hline C16:0 & 17.1 & 4.10 \\
\hline C16:1 cis-9 & 0.21 & nd \\
\hline $\mathrm{C} 17: 0$ & 0.15 & nd \\
\hline C17:1 cis-9 & 0.06 & nd \\
\hline C18:0 & 6.65 & 3.60 \\
\hline C18: 1 trans -4 to trans -16 & 4.76 & nd \\
\hline C18:1 cis-9 & 18.6 & 27.4 \\
\hline C18: 1 cis -11 to cis -13 & 2.33 & nd \\
\hline Non-conjugated C18:2 isomers & 0.84 & nd \\
\hline C18:2 cis-9, cis-12 & 35.3 & 1.20 \\
\hline C18:3 cis-9, cis- 12, cis- 15 & 3.09 & nd \\
\hline CLA cis-9, trans -11 & 0.16 & 29.8 \\
\hline CLA trans-9, cis-11 & 0.07 & nd \\
\hline CLA trans -10, cis -12 & nd & 29.9 \\
\hline$\sum$ Long chain FA $(>C 18)$ & 1.49 & nd \\
\hline$\sum$ Unidentified & 4.52 & 3.00 \\
\hline
\end{tabular}

nd: not detected ( $<0.01 \mathrm{~g} / 100 \mathrm{~g}$ of total fatty acids).

a Control = calcium salts of fatty acids (Megalac-E, Church \& Dwight Co., Nova Ponte, Brazil); CLA = supplement containing 29.9\% of trans-10, cis-12 conjugated linoleic acid as methyl ester (Luta-CLA 60, BASF AG, São Paulo, Brazil).

Treatments were fed via the concentrate, thus every goat received $15 \mathrm{~g}$ per feeding of its respective treatment.

\subsection{Measurements, sampling and analysis}

Concentrate intake was individually recorded and the silage intake was recorded for each pen throughout the study. Feeds were sampled and pooled by week, and stored at $-20^{\circ} \mathrm{C}$ before being analyzed according to AOAC (2000) for DM (method 934.01), EE (method 920.29) and CP (method 988.05), whereas NDF, ADF, neutral and acid-detergent insoluble nitrogen and lignin concentration were determined according to Van Soest et al. (1991).

After afternoon milking on the first and last day of each experimental period, goats were weighed and blood samples from the jugular vein were collected. A 10-mL Vacutainer tube (Zhejiang Kangshi Medical Devices Co., Hangzhou, China) containing EDTA was used and immediately placed on ice before centrifugation $(2800 \times g, 15 \mathrm{~min}$, room temperature). Plasma obtained was stored at $-20^{\circ} \mathrm{C}$ for glucose, insulin and non esterified fatty acids (NEFA) analysis. The concentration of NEFA was determined by a colorimetric-enzymatic method (NEFAC; Wako Pure Chemical Industries, Osaka, Japan) using 96-well plate. Glucose analysis was performed by direct reading (glucose oxidase enzyme immobilized in membrane) on an YSI 2700 Select autoanalyzer (biochemistry analyzer; Yellow Springs Instrument Co. Inc., Yellow Springs, $\mathrm{OH}$ ) and insulin by RIA (UNESP/Botucatu, Endocrinology laboratory, Botucatu, Brazil). 
Table 3

Performance and milk composition of lactating goats fed Control or CLA supplement.

\begin{tabular}{|c|c|c|c|c|c|c|}
\hline \multirow[t]{2}{*}{ Variable } & \multicolumn{2}{|l|}{ TRT $^{\mathrm{a}}$} & \multirow[t]{2}{*}{$\mathrm{SEM}^{\mathrm{b}}$} & \multicolumn{3}{|c|}{$P$-value } \\
\hline & Control & CLA & & TRT & Time & TRT $\times$ time \\
\hline BW, kg & 39.9 & 40.0 & 2.20 & 0.63 & 0.81 & 0.81 \\
\hline Silage intake, $\mathrm{kg}$ of dry matter/pen & 1.08 & 1.01 & 0.26 & *** & & \\
\hline Milk yield, kg/day & 2.47 & 2.46 & 0.25 & 0.12 & *** & $* * *$ \\
\hline Fat, \% & 2.95 & 2.54 & 0.17 & ${ }_{* * *}^{* * *}$ & *** & $* * *$ \\
\hline Protein, \% & 2.67 & 2.67 & 0.18 & 0.93 & ${ }^{* * *}$ & ${ }^{* *}$ \\
\hline Lactose, \% & 4.17 & 4.14 & 0.09 & & ${ }^{* * *}$ & $* * *$ \\
\hline Fat yield, g/day & 71.4 & 61.9 & 8.47 & *** & $* * *$ & $* * *$ \\
\hline Protein yield, g/day & 64.6 & 64.4 & 6.11 & 0.69 & *** & $* * *$ \\
\hline Lactose yield, g/day & 101.4 & 100.4 & 10.2 & 0.30 & *** & 0.44 \\
\hline SCC, linear score ${ }^{c}$ & 5.53 & 5.41 & 0.79 & 0.12 & 0.39 & 0.65 \\
\hline $\mathrm{NE}$ in milk, Mcal/ $\mathrm{kg}^{\mathrm{d}}$ & 0.58 & 0.54 & 0.02 & $* * *$ & $* * *$ & \\
\hline
\end{tabular}

a Treatments (TRT): Control=calcium salts of fatty acids (Megalac-E, Church \& Dwight Co., Nova Ponte, Brazil); CLA=supplement containing 29.9\% of trans-10, cis-12 conjugated linoleic acid as methyl ester (Luta-CLA 60, BASF AG, São Paulo, Brazil).

b Standard error of mean for $n=20$.

c Linear score of the somatic cell count $(\mathrm{SCC})$ : [LNSCC $=\mathrm{LN}(\mathrm{SCC} / 100) /(0.693147)+3]$ (National Mastitis Council, 1996).

d Net energy $(\mathrm{N}) \mathrm{E}$ in milk $(\mathrm{Mcal} / \mathrm{kg})=0.0929 \times \%$ fat $+0.0547 \times \%$ crude protein $+0.0395 \times \% \mathrm{l}$ actose $(\mathrm{NRC}, 2001)$.

${ }^{*} P<0.05$

** $P<0.01$.

*** $P<0.001$.

Milk yield was individually recorded at each milking throughout the study. Milk samples were taken every 2 days and stored at $4{ }^{\circ} \mathrm{C}$ with a preservative (bromopol tablet; D \& F Control Systems Inc., San Ramon, CA) until analyzed of fat, protein, lactose, total solids (AOAC, 2000; method 972.160) using infrared analysis and somatic cell count (SCC) by flow cytometry (BactoCount IBC 100, Bentley Instruments, Curitiba, Paraná, Brazil) in the same day. Additional milk samples for FA analysis were collected on the last day of each treatment period (day 14) and frozen at $-20^{\circ} \mathrm{C}$ without preservative. FA present in milk fat and lipid supplements were analyzed according the procedures describe in the paper of Baldin et al. (2013).

\subsection{Assumptions and calculations}

The CLA dose was the same used by Baldin et al. (2013) and a 95\% rumen biohydrogenation of the unprotected CLA supplement was assumed (Jenkins et al., 2008).

Transfer efficiency for trans-10, cis-12 CLA into milk fat was calculated by comparing dietary intake and milk fat secretion (Lock et al., 2008). Eq (5) of De Veth et al. (2004) was used to estimate abomasal flow of trans10 , cis-12 CLA based on milk trans-10, cis-12 CLA and assumed that the transfer efficiency of absorbed CLA into milk is similar across ruminant species. Rumen biohydrogenation of trans-10, cis-12 CLA was estimated based on dietary intake. In all calculations, milk fat content of trans-10, cis12 CLA in CLA treatment was first corrected for the content of this isomer in Control milk fat.

The energy balance (EB, Mcal de metabolizable energy - ME) was calculated as: MEintake - MEmilk - MEmaintenance (NRC, 2001), where MEintake was calculated from observed DMI and a calculated diet ME content plus ME value of the lipid supplements provided by the manufacturer (Megalac-E: 7.1 and Luta-CLA 60: 8.8 Mcal/kg). MEmilk was estimated from the net energy (NE) in milk correcting for the efficiency of use of MEintake for production as indicated by Nsahlai et al. (2004): MEmilk=NEmilk/0.589. NEmilk was obtained from the NRC (1989) equation: NEmilk $=$ milk yield $\times[1.4694+(0.4025 \times$ milk fat \% $)]$, and MEmaintenance $=110 \mathrm{kcal} \times \mathrm{BW}^{0.75}(\mathrm{NRC}, 2007)$.

\subsection{Statistical analysis}

Data were analyzed in a crossover design using SAS (SAS Inst. Inc., Cary, NC). Milk yield, yield and concentration of milk components, DMI, BW, BE, net energy in milk and SCC were analyzed as repeated measures using the PROC MIXED. The model contained effects of day of measurement, treatment and the interaction between both. Goats were the random effect, and day of treatment, treatment and the interaction fixed effects. The effects of sequence (Control to CLA or CLA to Control) and treatments (Control or CLA) were assigned as fixed factors and the effects of period ( 1 or 2 ) and animal within sequence were assumed to be random factors, except that no carryover effect was accounted for in the model due to insufficient degrees of freedom. Milk FA profile, NEFA, glucose and insulin were analyzed using a reduced model in PROC MIXED without repeated measures. For repeated measures variables the Autoregressive 1 variance-(co) variance matrix was chosen according the lowest Akaike information.

\section{Results}

All animals remained healthy during the experiment and no mastitis was detected. The concentrate containing the dietary treatments was completely consumed by each goat.

Performance and milk composition are showed in Table 3. CLA decreased $(P<0.001)$ milk fat content and yield by 13.9 and $13.3 \%$, respectively. Compared to Control, CLA treated goats consumed $6.5 \%$ less corn silage $(P<0.001)$, but had no effect on MY or BW $(P>0.05)$. Milk protein content and milk protein and lactose yield were unaffected by treatments, although milk lactose content was slightly lower (<1\% change) in the CLA-treated goats (Table 3 ).

Milk FA profile is presented in Table 4. Interestingly was the increase in the milk fat content of cis-9, trans-11 CLA (29.6\%) in CLA treated goats, even though the amount of cis9, trans-11 CLA being secreted into milk was not affected by treatment because of the reduced milk fat yield (Control: 0.37 , CLA: $0.35 \mathrm{mg} /$ day, $P>0.05$ ). There was a 17 fold increase in milk fat content of trans-10, cis-12 CLA which increased its secretion into milk (13.3 vs. $195.9 \mathrm{mg} /$ day) when goats received the CLA treatment $(P<0.001)$.

Table 5 shows the milk fat profile according the origin of FA. The CLA treatment reduced the desaturase index for all pairs of FA examined $(P<0.05)$. When categorized according to the origin, de novo synthesized FA $(<\mathrm{C} 16)$, FA up taken from the circulation $(>\mathrm{C} 16)$ and derived from both sources (C16) had their concentration in milk fat changed by $-13.2,+15.5$ and $-9.5 \%$, respectively, in response to CLA treatment $(P<0.001)$. Despite that, the daily secretion of $<$ C16, C16 and $>$ C16 FA was lower $(P<0.001)$ in 
Table 4

Milk fatty acid profile of lactating goats fed Control or CLA supplement.

\begin{tabular}{|c|c|c|c|c|}
\hline \multirow{2}{*}{$\begin{array}{l}\text { Fatty acid } \\
\text { (g/100 g of total fatty acid) }\end{array}$} & \multicolumn{2}{|c|}{ Treatment $^{\mathrm{a}}$} & \multirow[t]{2}{*}{$\mathrm{SEM}^{\mathrm{b}}$} & \multirow[t]{2}{*}{$P$-value } \\
\hline & Control & CLA & & \\
\hline $\mathrm{C} 4: 0$ & 2.74 & 2.97 & 0.14 & $* *$ \\
\hline $\mathrm{C} 6: 0$ & 2.58 & 2.17 & 0.14 & ${ }^{* * *}$ \\
\hline C8:0 & 2.76 & 2.06 & 0.18 & $* * *$ \\
\hline C10:0 & 8.82 & 6.51 & 0.70 & $* * *$ \\
\hline C11:0 & 0.19 & 0.09 & 0.01 & $* * *$ \\
\hline C12:0 & 3.61 & 2.84 & 0.55 & $* * *$ \\
\hline C14:0 & 8.85 & 8.77 & 0.22 & 0.57 \\
\hline $\mathrm{C} 15: 0$ iso & 0.25 & 0.24 & 0.01 & 0.09 \\
\hline C15:0 anteiso & 0.41 & 0.43 & 0.01 & 0.08 \\
\hline C14:1 cis-9 & 0.08 & 0.05 & 0.01 & $* *$ \\
\hline C15:0 & 0.68 & 0.71 & 0.02 & 0.08 \\
\hline C16:0 & 25.6 & 23.2 & 0.95 & $* * *$ \\
\hline C16:1 cis-9 & 0.43 & 0.35 & 0.02 & ${ }^{* * *}$ \\
\hline $\mathrm{C} 17: 0$ & 0.50 & 0.52 & 0.01 & 0.14 \\
\hline C17:1 cis-9 & 0.18 & 0.13 & 0.01 & $* * *$ \\
\hline C18:0 & 14.1 & 21.5 & 0.63 & $* * *$ \\
\hline C18: 1 trans -4 & 0.02 & 0.03 & 0.01 & ${ }^{*}$ \\
\hline C18: 1 trans -5 & 0.03 & 0.04 & 0.01 & 0.44 \\
\hline C18: 1 trans $-6+$ trans $-7+$ trans -8 & 0.14 & 0.27 & 0.01 & $* * *$ \\
\hline C18:1 trans -9 & 0.29 & 0.35 & 0.01 & $* * *$ \\
\hline C18:1 trans -10 & 0.53 & 1.24 & 0.06 & $* * *$ \\
\hline C18:1 trans -11 & 1.50 & 2.10 & 0.18 & ${ }^{* * *}$ \\
\hline C18:1 trans -12 & 0.38 & 0.52 & 0.02 & $* * *$ \\
\hline C18: 1 trans $-13+$ trans -14 & 0.46 & 0.59 & 0.04 & ${ }^{* * *}$ \\
\hline C18: 1 cis $-9+$ trans -15 & 18.3 & 15.5 & 0.91 & $* * *$ \\
\hline C18: 1 cis -11 & 0.98 & 0.98 & 0.07 & 0.89 \\
\hline C18:1 cis-12 & 0.46 & 0.54 & 0.02 & $* *$ \\
\hline C18:1 cis-13 & 0.07 & 0.07 & 0.01 & 0.97 \\
\hline C18:1 trans -16 & 0.41 & 0.34 & 0.08 & 0.20 \\
\hline C18:2 cis-9 trans-12 & 0.04 & 0.03 & 0.01 & ${ }^{* *}$ \\
\hline C18:2 cis-9 cis-12 & 2.80 & 2.55 & 0.11 & ${ }^{* *}$ \\
\hline $\mathrm{C} 20: 0$ & 0.22 & 0.26 & 0.01 & ** \\
\hline C20:1 cis- 11 & 0.04 & 0.06 & 0.01 & ${ }^{*}$ \\
\hline C18:3 cis-9, cis- 12, cis -15 & 0.16 & 0.13 & 0.01 & ${ }^{* * *}$ \\
\hline C18:2 cis-9, trans-11 CLA & 0.54 & 0.70 & 0.04 & ${ }^{* * *}$ \\
\hline C18:2 trans-10, cis-12 CLA & 0.02 & 0.34 & 0.04 & $* * *$ \\
\hline C20:2 cis- 11, cis -14 & 0.01 & 0.01 & 0.01 & 0.08 \\
\hline $\mathrm{C} 22: 0$ & 0.05 & 0.06 & 0.01 & 0.20 \\
\hline C20:3 cis- 8, cis- 11, cis -14 & 0.02 & 0.02 & 0.01 & 0.42 \\
\hline C20:4 cis-5, cis-8, cis- 11, cis- 14 & 0.20 & 0.16 & 0.01 & ${ }^{* * * *}$ \\
\hline $\mathrm{C} 24: 0$ & 0.03 & 0.02 & 0.01 & $* *$ \\
\hline$\sum$ Unidentified & 0.31 & 0.27 & 0.12 & 0.62 \\
\hline
\end{tabular}

a Treatments (TRT): Control=calcium salts of fatty acids (Megalac-E, Church \& Dwight Co., Nova Ponte, Brazil); CLA: supplement containing $29.9 \%$ of trans-10, cis-12 conjugated linoleic acid as methyl ester (Luta-CLA 60, BASF AG, São Paulo, Brazil).

b Standard error of mean for $n=20$.

${ }^{*} P<0.05$.

** $P<0.01$.

*** $P<0.001$.

the CLA treatment (20.9 vs. $17.2,17.3$ vs. 13.2 and 28.2 vs. $24.1 \mathrm{~g} /$ day, respectively).

The transfer efficiency of trans-10, cis-12 CLA from the dietary supplement into milk fat was $1.8 \%$. In CLA treated goats, $0.67 \mathrm{~g} /$ day of trans-10, cis-12 CLA is estimated to have flowed to the abomasum providing a ruminal escape of $7.5 \%$.

Key plasma metabolites and metabolic hormones are presented in Table 6. Glucose and insulin were not affected by treatments $(P>0.05)$ while NEFA was decreased by $22.2 \%$ in CLA treatment $(P=0.002)$. At the beginning of the supplementation period (day 0 ), the EB did not differ between Control and CLA $(P>0.05)$. At the end (day 14) however, treatments differed $(P<0.01)$ with CLA treated

\section{Table 5}

Summation by source, degree of unsaturation and desaturase indexes in milk fat of lactating goats fed Control or CLA supplement.

\begin{tabular}{|c|c|c|c|c|}
\hline \multirow{2}{*}{$\begin{array}{l}\text { Fatty acid } \\
\text { (g/100 g of total fatty acid) }\end{array}$} & \multicolumn{2}{|c|}{ Treatment $^{\mathrm{a}}$} & \multirow[t]{2}{*}{$\mathrm{SEM}^{\mathrm{b}}$} & \multirow[t]{2}{*}{$P$-value } \\
\hline & Control & CLA & & \\
\hline$\sum<\mathrm{C} 16$ & 31.1 & 27.0 & 1.04 & *** \\
\hline$\sum \mathrm{C} 16$ and $\mathrm{C} 16: 1$ & 26.0 & 23.6 & 0.96 & **** \\
\hline$\sum>\mathrm{C} 16$ & 42.5 & 49.1 & 0.71 & *** \\
\hline \multicolumn{5}{|l|}{ Desaturase indexes ${ }^{c}$} \\
\hline $\mathrm{C} 14: 1$ cis-9/C14:0 & 0.009 & 0.006 & 0.001 & ${ }^{* *}$ \\
\hline C16:1 cis-9/C16:0 & 0.017 & 0.016 & 0.001 & * \\
\hline $\mathrm{C} 17: 1$ cis $-9 / \mathrm{C} 17: 0$ & 0.257 & 0.192 & 0.007 & *** \\
\hline C18:1 cis-9/C18:0 & 0.564 & 0.420 & 0.019 & $* * *$ \\
\hline CLA cis -9, trans $-11 /$ C $18: 1$ trans -11 & 0.273 & 0.259 & 0.012 & * \\
\hline
\end{tabular}

a Treatments (TRT): Control=calcium salts of fatty acids (Megalac-E, Church \& Dwight Co., Nova Ponte, Brazil); CLA = supplement containing $29.9 \%$ of trans-10, cis-12 conjugated linoleic acid as methyl ester (Luta-CLA 60, BASF AG, São Paulo, Brazil).

b Standard error of mean for $n=20$.

c Values represent ratio of product/(substrate + product) for stearoylCoA desaturase enzyme.

${ }^{*} P<0.05$.

** $P<0.01$.

*** $P<0.001$.

Table 6

Metabolic parameters of lactating goats fed control or CLA supplement.

\begin{tabular}{|c|c|c|c|c|}
\hline \multirow[t]{2}{*}{ Variable } & \multicolumn{2}{|c|}{ Treatment $^{\mathrm{a}}$} & \multirow[t]{2}{*}{$\mathrm{SEM}^{\mathrm{b}}$} & \multirow[t]{2}{*}{$P$-value } \\
\hline & Control & CLA & & \\
\hline Insulin, $\mu \mathrm{g} / \mathrm{mL}$ & 0.88 & 1.44 & 0.33 & 0.38 \\
\hline Glucose, mg/dL & 56.2 & 57.8 & 0.77 & 0.17 \\
\hline NEFA, mmol/L & 0.27 & 0.21 & 0.02 & \\
\hline EB d0, Mcal/day; $b^{c}$ & -0.17 & -0.51 & 0.57 & 0.09 \\
\hline EB d14, Mcal/day & 0.23 & 0.53 & 0.40 & \\
\hline
\end{tabular}

a Treatments (TRT): Control = calcium salts of fatty acids (Megalac-E, Church \& Dwight Co., Nova Ponte, Brazil); CLA = supplement containing $29.9 \%$ of trans-10, cis-12 conjugated linoleic acid as methyl ester (Luta-CLA 60, BASF AG, São Paulo, Brazil).

b Standard error of mean for $n=20$.

c Energy Balance $=\mathrm{ME}_{\text {intake }}-\mathrm{ME}_{\text {milk }}-\mathrm{ME}_{\text {maintenance }}(\mathrm{NRC}, 2001)$.

${ }^{*} P<0.05$.

** $P<0.01$.

*** $P<0.001$.

NEFA: non esterified fatty acids.

goats having the calculated EB 130\% higher than goats under the control treatment (Table 6).

\section{Discussion}

Unsaturated fatty acids such as C18:2 are extensively metabolized by ruminal bacteria and the rate and extent of biohydrogenation is dependent on the microbial community and physical form of the fatty acid (Jenkins et al., 2008). Importantly, particle size is a key factor determining rumen retention of feeds (Mertens, 2005) and is expected to impact the extent of biohydrogenation. In this study, unprotected CLA was fed mixed with concentrate attempting to increase the amount of trans-10, cis-12 CLA escaping ruminal biohydrogenation. Based on the amount found in milk fat we calculated that $92.5 \%$ of the trans-10, cis-12 CLA fed was ruminally biohydrogenated. Interesting, when a similar CLA supplement was blended with wheat middling and molasses and fed to dairy cows $99.8 \%$ of the trans-10, cis-12 CLA was biohydrogenated (Dohme-Meier 
and Bee, 2012). The greater ruminal escape of trans-10, cis-12 CLA in goats compared to cows might be related to the passage rate of rumen digesta. According to Van Soest (1997), rumen turnover is related to the animal's weight raised to the power of 0.25 , therefore rumen turnover in goats is expected to be higher than cows. In addition, feeding unprotected CLA via concentrate may have reduced its rumen retention time or its availability in the rumen. Of note, CLA ruminal biohydrogenation was estimated according to De Veth et al. (2004) and assumed similar trans-10, cis-12 CLA intestinal absorption and transfer to milk between cows and goats.

The biohydrogenation of unprotected polyunsaturated FA is expected to be greater than $90 \%$ (Jenkins et al., 2008). The transfer efficiency of trans-10, cis-12 CLA from feed to milk in the current study was $1.8 \%$ and was comparable to values of 1.89\% (Lock et al., 2008) and 2.22\% (Shingfield et al., 2009) reported when goats were fed equivalent doses of rumen protected trans-10, cis-12 CLA. The equivalent transfer efficiency suggests a low degree of ruminal protection in lipid-encapsulated (Lock et al., 2008) and calcium salts (Shingfield et al., 2009) of CLA, rather than high transfer efficiency for the unprotected CLA supplement. However, if unprotected and protected CLA supplements are of comparable efficacy, the feeding of unprotected CLA may be advantageous as preparation of rumen protected sources may dilute trans-10, cis-12 CLA and increase the amount of total fat supplement required in the diet, which may adversely affect diet palatability.

In this study, CLA treatment considerably increased trans-10, cis-12 CLA content and secretion into milk fat. In dairy cows it was established a strong relationship between abomasal infusion level of trans-10, cis-12 CLA and its secretion into milk fat (De Veth et al., 2004). Limited data suggested that when calcium salts of CLA were fed to dairy goats (Shingfield et al., 2009), trans-10, cis-12 CLA content continually increased across all CLA doses. We did not examine dose-responses, but because the large amount found in milk fat in the current study and previous unprotected CLA observations in dairy cattle (Dohme-Meier and Bee, 2012), it is reasonable to expect that trans-10, cis-12 CLA secreted into milk also correlates to the quantity of unprotected CLA fed in the diet.

Studies on MFD and its regulation have demonstrated that trans-10, cis-12 CLA is a potent inhibitor of milk fat synthesis (Bauman et al., 2011). Not surprising, the large increase of trans-10, cis-12 CLA in milk was accompanied by decreased milk fat content and yield (13.9 and 13.3\%, respectively). According to our initial assumption, $30 \mathrm{~g} /$ day of CLA supplement was expected to decrease milk fat around $20-25 \%$. Less pronounced CLA induced MFD is not unexpected as goats have been shown to be less sensitive to the trans-10, cis-12 CLA inhibition of milk fat synthesis (Shingfield et al., 2009). But intriguing, the observed MFD is bellow than the range previously reported (17.5-21\%) in studies supplementing goats with similar doses of trans-10, cis-12 CLA (Lock et al., 2008; Shingfield et al., 2009), even having similar content of trans-10, cis-12 CLA in milk fat. Methyl esters of CLA were shown to be as effective as free FA to induce MFD when infused post-ruminally in dairy cows (De Veth et al., 2004). We suspect that the lower MFD
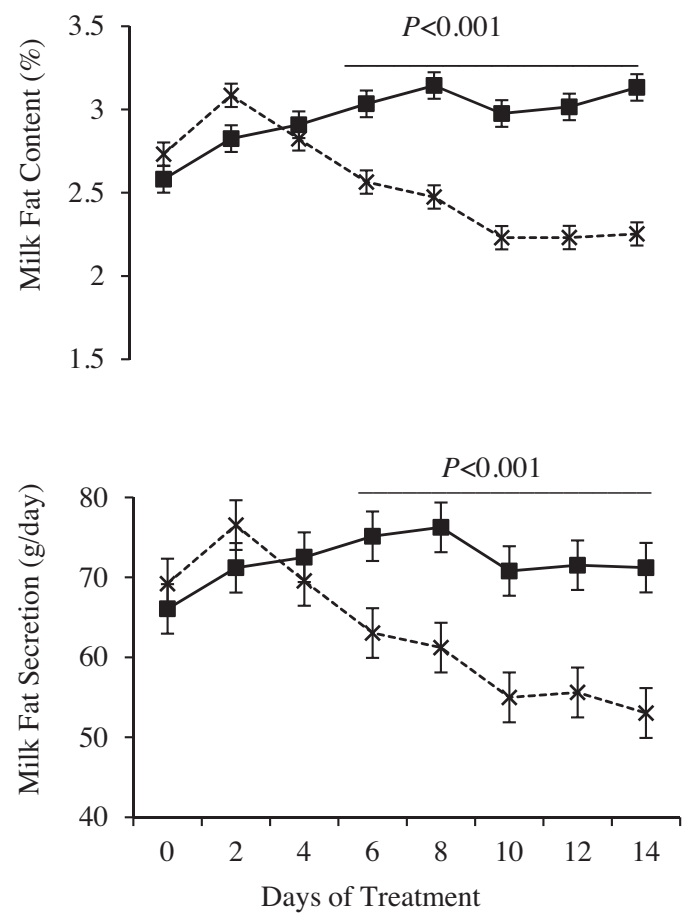

Fig. 1. Temporal variation in milk fat content $(A)$ and yield (B) of lactating goats fed control $(\mathbf{\square}, n=20)$ or rumen unprotected CLA $(\times, n=20)$ supplement. The standard error of the mean is indicated by the error bars over each point.

observed in this study might arise from interactions with animal factors, such as a genetic less responsiveness to the trans-10, cis-12 CLA.

Milk fat depression is correlated with increased trans10 18:1 in cows (Griinari et al., 1998), but this association has not been confirmed in goats due to the large variability among studies (Chilliard et al., 2003). In this study, a negative correlation $\left(r^{2}=0.83 ; P<0.001\right.$; data not shown) was observed between the concentration of trans-10 18:1 in milk and milk fat content. Griinari et al. (1999) showed a positive correlation $\left(r^{2}=0.7\right)$ between trans-10 18:1 and trans-10, cis-12 CLA in milk fat. We do not exclude the idea that besides trans-10, cis-12 CLA other FA might have contributed to the observed MFD, but we expected that trans-10, cis-12 CLA was the major inhibitor of milk fat synthesis.

The mechanism of trans-10, cis-12 CLA induced MFD has been well characterized (Baumgard et al., 2002; Harvatine and Bauman, 2006). Briefly, lipogenic capacity and transcription of key mammary lipogenic genes and transcription factors are coordinately down-regulated in mammary gland (Bauman et al., 2011). Although changes in mammary tissue were not directly analyzed, the current study provides insight into changes in metabolic pathways involved in milk fat synthesis. For example, decreases in milk fat concentration and yield were not seen before day 4 of CLA treatment (Fig. 1). This matches with the halflife (48-72 h) of Acetyl-CoA Carboxylase and Fatty Acid Synthase (Craig et al., 1972; Volpe and Vagelos, 1973), two of key lipogenic enzymes involved in the coordinated mechanism in which CLA causes MFD (Baumgard et al., 




Fig. 2. Milk fatty acid (FA) secretion in lactating goats fed control ( $\square$ $n=20$ ) or rumen unprotected $\operatorname{CLA}(\square, n=20)$ supplement. Standard error of the mean is indicated by error bars over each column. Treatments effects with significance differences are indicated by letters over the columns $(P<0.001$ for all $)$.

2002). Similarly, when goats received the CLA treatment we observed a reduction in the yield of both de novo synthesized and preformed FA (Fig. 2). This is in agreement with previous CLA studies in dairy cows showing that trans-10, cis-12 CLA reduces mammary tissue abundance of mRNA for lipogenic genes encoding key enzymes involved in de novo FA synthesis, FA uptake and transport, desaturation and triacylglycerol synthesis (Harvatine et al., 2009). Further, the reduction in the secretion of short and medium-chain FA (C4 to C16) accounted for over 75\% ( $13.18 \mathrm{~g} /$ day) of the total reduction (17.37 g/day; Fig. 2). A greater inhibition of the de novo pathway is frequently observed during CLA induced MFD (Bauman et al., 2011). Lastly, Stearoyl-CoA Desaturase (SCD) catalyzes the c9desaturation of SFA to MUFA derivatives (Corl et al., 2001), has also been shown to be down-regulated by trans-10, cis12 CLA (Harvatine and Bauman, 2006). Similarly, in this study the reduction in all calculated desaturase indexes (Table 5) reflects the drop in SCD activity when goats received CLA.

In previous reports where rumen protected CLA containing similar amounts of cis-9, trans-11 and trans-10, cis-12 isomers was fed, elevated levels of both CLA isomers were found in the milk (Lock et al., 2008; Shingfield et al., 2009). Milk fat content of cis-9, trans-11 CLA did increase in CLA treated goats, but in a ratio substantially smaller than for trans-10, cis-12 CLA. It is expected that both isomers were equally biohydrogenated in the rumen, thus we speculate a few possibilities to explain this difference. First, trans-10, cis-12 CLA inhibition of SCD in the mammary gland may decrease the conversion of trans-11 18:1 to cis9, trans-11 CLA in CLA treated goats (Table 5). Secondly, cis-9, trans-11 CLA level may have been increased in Control treated animals arising from the dissociation of $\mathrm{C} 18: 2$ rich calcium salts of fatty acids in the rumen (Harvatine and Allen, 2006), increasing mammary synthesis of cis9, trans-11 CLA from ruminally derived trans-11 18:1 (Corl et al., 2001). Lastly, the unprotected CLA increased rumen synthesis of trans-10, cis-12 CLA from the 18:2 fatty acids present in the basal diet. Importantly, the feeding of unprotected CLA increased milk fat concentration of trans10 , cis-12 CLA and maintained secretion of this isomer into milk at levels equal to the Control despite the reduced milk fat yield and desaturase indexes.

Inhibition of milk fat synthesis and changes in milk FA profile is the typical phenotype arising from trans-10, cis-12 CLA supplementation. Other milk components (e.g. protein, lactose) are generally unaffected (Bauman et al., 2011), and results of the present study are consistent with this. However, the CLA inhibition of milk fat synthesis reduces energy required for milk production, which may result in "secondary" CLA effects such as changes in milk yield, DMI and EB. In the present study, goats experiencing MFD under CLA treatment did not increase milk yield, but consumed less forage (Table 3 ) and had improved calculated EB after 14 days of CLA supplementation (Table 6). These "secondary" CLA effects are also linked to other important production parameters (e.g. nutrients intake, stage of lactation, body condition score), which explains their large variability among CLA studies. For instance, long-term CLA supplementation of lactating dairy cows in tropical pasture, where the intake of energy is generally insufficient to meet the animals requirements, resulted in increased milk yield and milk protein content (Medeiros et al., 2010). Improved $\mathrm{EB}$, bioenergetic variables and increased milk yield was also observed with trans-10, cis-12 CLA plus ad libitum feeding of a total mixed ration (Odens et al., 2007). However, cows experiencing CLA induced MFD in early lactation did not have a significant increase either on milk yield or net EB (Castaneda-Gutierrez et al., 2005).

In the current study goats may have already expressed their maximum genetic potential for milk production, and therefore portioned energy spared from milk fat synthesis towards improving EB rather than milk synthesis. Harvatine et al. (2009) demonstrated that lipid synthesis was increased in adipose tissue during short-term CLA induced MFD, but in the present study CLA treated goats had improved EB with no changes in BW, however the short periods make observation of changes in BW difficult. Although no BW changes were observed, the mid/late lactation goats in reasonable body condition (data not shown) in the current experiment appear to have had reduced DMI instead (6.5\% reductions in corn silage intake). Intake is regulated to meet animal's requirements, particularly for energy (Forbes, 2005), and this would explain the reduction in DMI when goats in reasonable body condition had energy spared by CLA induced MFD with no changes in either milk yield or BW. Intake did not completely account for the reduced milk fat synthesis though, which resulted in the improved EB.

Circulating NEFA level closely reflects whole-animal $\mathrm{EB}$, and compared to Control group CLA treated goats had a $22.2 \%$ reduction in serum NEFA, which substantiates the improved calculated EB. Previous CLA studies in dairy goats have not monitored metabolic parameters. The change in NEFA results is in agreement with some reports in dairy cows (Odens et al., 2007), however others have not observed no change in plasma. Overall, changes in metabolic parameters seem to be more likely a consequence of the CLA induced MFD rather than a direct effect of CLA on animal's overall metabolism. 


\section{Conclusion}

Feeding rumen unprotected CLA methyl ester via concentrate feed reduced milk fat synthesis, reduced feed intake, and improved calculated EB in dairy goats. The phenotype for milk fat depression followed the pattern previously described in dairy cows, which began approximately 4 days after CLA supplementation and involved an inhibition on the synthesis of FA of all chain lengths, although de novo synthesis was decreased to a greater extent. The magnitude of CLA induced milk fat depression was sufficient to induce secondary responses such as improved EB and lower circulating plasma NEFA. Overall, CLA methyl ester supplement may be used in dairy goat farms as a nutritional tool to induce a controlled MFD.

\section{Conflict of interest statement}

None.

\section{Acknowledgments}

The authors gratefully acknowledge National Council for Scientific and Technological Development - CNPq (Project 556927/2010-9 - Edital MCT/CNPq 070/2009) for the grant to D. E. Oliveira (Scholarship to R. Dresch), FAPEMIG (Project CVZ APQ 02187/09) for the financial support and Mr. Ariovaldo Zanni for the donation of the unprotected CLA supplement (BASF AG, São Paulo, Brazil). The authors also would like to thank Dr. José Henrique Bruschi in memorian.

\section{References}

AOAC, 2000. Official Methods of Analysis, 17th ed. Association of Official Analytical Chemists, Arlington, VA, USA.

Baldin, M., Gama, M.A.S., Dresch, R., Harvatine, K.J., Oliveira, D.E., 2013. A rumen unprotected conjugated linoleic acid (CLA) supplement inhibits milk fat synthesis and improves energy balance in lactating goats. J. Anim. Sci. 91, 3305-3314.

Baumgard, L.H., Corl, B.A., Dwyer, D.A., Saebø, A., Bauman, D.E., 2000. Identification of the conjugated linoleic acid isomer that inhibits fat synthesis. Am. J. Physiol. Regul. Integr. Comp. Physiol. 278, R179-R184

Baumgard, L.H., Matitashavii, E., Corl, B.A., Dwyer, D.A., Bauman, D.E., 2002. Trans-10, cis-12 conjugated linoleic acid decreases lipogenic rates and expression of genes involved in milk lipid synthesis in dairy cows. J. Dairy Sci. 85, 2155-2163.

Bauman, D.E., Harvatine, K.J., Lock, A.L., 2011. Nutrigenomics, rumenderived bioactive fatty acids, and the regulation of milk fat synthesis. Ann. Rev. Nutr. 31, 299-319.

Castaneda-Gutierrez, E., Overton, T.R., Butler, W.R., Bauman, D.E., 2005. Dietary supplements of two doses of calcium salts of conjugated linoleic acid during the transition period and early lactation. J. Dairy Sci. 88, 1078-1089.

Chilliard, Y., Ferlay, A., Rouel, J., Lamberet, G., 2003. A review of nutritional factors affecting goat milk lipid synthesis and lipolysis. J. Dairy Sci. 86 $1751-1770$.

Craig, M.C., Nepokroeff, C.M., Lakshmanan, M.R., Porter, J.W., 1972. Effect of dietary change on the rates of synthesis and degradation of rat liver fatty acid synthetase. Arch. Biochem. Biophys. 152, 619-630.

Corl, B.A., Baumgard, L.H., Dwyer, D.A., Griinari, J.M., Phillips, B.S., Bauman, D.E., 2001. The role of $\Delta 9$-desaturase in the production of cis-9, trans11 CLA. J. Nutr. Biochem. 12, 622-630.

De Veth, M.J., Griinari, J.M., Pfeiffer, A.M., Bauman, D.E., 2004. Effect of CLA on milk fat synthesis in dairy cows: comparison of inhibition by methyl esters and free fatty acids and relationships among studies. Lip 39, 365-372.
Dohme-Meier, F., Bee, G., 2012. Feeding unprotected CLA methy esters compared to sunflower seeds increased milk CLA level but inhibited milk fat synthesis in cows. Asian-Aust. J. Anim. Sci 25 , $75-85$.

Forbes, J.M., 2005. Voluntary feed intake and diet selection. In: Dijkstra, J., Forbes, J.M., France, J. (Eds.), Quantitative Aspects of Ruminant Digestion and Metabolism. CABI, Publishing, Cambridge, MA, USA, pp. 607-625.

Griinari, J.M., Dwyer, D.A., McGuire, M.A., Bauman, D.E., Palmquist, D.L., Nurmela, K.V.V., 1998. Trans-octadecenoic acids and milk fat depression in lactating dairy cows. J. Dairy Sci. 81, 1251-1261.

Griinari, J.M., Nurmela, K., Dwyer, D.A., Barbano, D.M., Bauman, D.E., 1999 Variation of milk fat concentration of conjugated linoleic acid and milk fat percentage is associated with a change in ruminal biohydrogenation. J. Dairy Sci. 77, 117-118 (Abstr.).

Harvatine, K.J., Bauman, D.E., 2006. SREBP1 and thyroid hormone responsive Spot 14 (S14) are involved in the regulation of bovine mammary lipid synthesis during diet-induced milk fat depression and treatment with CLA. J. Nutr. 136, 2468-2474.

Harvatine, K.J., Perfield, J.W., Bauman, D.E., 2009. Expression of enzymes and key regulators of lipid synthesis is upregulated in adipose tissue during CLA-induced milk fat depression in dairy cows. J. Nutr. 139, 849-854.

Harvatine, K.J., Allen, M.S., 2006. Fat supplements affect fractional rates of ruminal fatty acid biohydrogenation and passage in dairy cows. J. Nutr. 136, 677-685.

Jenkins, T.C., Wallace, R.J., Moate, P.J., Mosley, E.E., 2008. Recent advances in biohydrogenation of unsaturated fatty acids within the rumen microbial ecosystem. J. Anim. Sci. 85, 2155-2163.

Lock, A.L., Rovai, M., Gipson, T.A., de Veth, M.J., Bauman, D.E., 2008. A conjugated linoleic acid supplement containing trans-10, cis-12 conjugated linoleic acid reduces milk fat synthesis in lactating goats. J. Dairy Sci. 91, 3291-3299

Medeiros, S.R., Oliveira, D.E., Aroeira, J.M., McGuire, M.A., Bauman, D.E., Lanna, D.P.D., 2010. Effects of dietary supplementation of rumenprotected conjugated linoleic acid to grazing cows in early lactation. J. Dairy Sci. 93, 1126-1137.

Mertens, D.R., 2005. Rate and extent of digestion. In: Dijkstra, J., Forbes J.M., France, J. (Eds.), Quantitative Aspects of Ruminant Digestion and Metabolism. CABI, Publishing, Cambridge, MA, USA, pp. $12-47$.

Moon, H.S., Lee, H.G., Chung, C.S., Choi, Y.J., Cho, C.S., 2008. Physicochemical modifications of conjugated linoleic acid for ruminal protection and oxidative stability. Nutr. Metab. 5, 1-11

NRC, 1989. Nutrient Requirements of Dairy Cattle, Natl. Acad. Sci., 6th rev. ed. National Academic Press, Washington, DC

NRC, 2001. Nutrient Requirements of Dairy Cattle, Natl. Acad. Sci., 7th rev ed. National Research Council, Washington, DC.

NRC, 2007. Nutrient Requirements of Small Ruminants: Sheep, Goats, Cervids, and New World Camelids, Natl. Acad. Sci., 1st ed. National Academic Press, Washington, DC.

Nsahlai, I.V., Goetsch, A.L., Luo, J., Johnson, Z.B., Moore, J.E., Sahlu, T., Ferrell, C.L., Galyean, M.L., Owens, F.N., 2004. Energy requirements for lactation of goats. Small Ruminant Res. 53, 253-273.

Oliveira, D.E., Gama, M.A.S., Fernandes, D., Tedeschi, L.O., Bauman, D.E., 2012. An unprotected conjugated linoleic acid supplement decreases milk production and secretion of milk components in grazing dairy ewes. J. Dairy Sci. 95, 1437-1446.

Odens, L.J., Burgos, R., Innocenti, M., VanBaale, M.J., Baumgard, L.H., 2007. Effects of varying doses of supplemental conjugated linoleic acid on production and energetic variables during the transition period. J. Dairy Sci. 90, 293-305

Shingfield, K.J., Rouel, J., Chilliard, Y., 2009. Effect of calcium salts of a mixture of conjugated linoleic acids containing trans-10, cis12 in the diet on milk fat synthesis in goats. Br. J. Nutr. 101, 1006-1019.

Tedeschi, L.O., Cannas, A., Fox, D.G., 2010. A nutrition mathematical model to account for dietary supply and requirements of energy and other nutrients for domesticated small ruminants: the development and evaluation of the Small Ruminant Nutrition System. Small Rum. Res. $89,174-184$

Van Soest, P.J., 1997. Interactions of feeding behaviour and forage composition. In: Proceedings of the IV International Conference on Goats, Brasilia, Brazil, pp. 971-987.

Van Soest, P.J., Robertson, J.B., Lewis, B.A., 1991. Methods for dietary fiber, neutral detergent fiber, and nonstarch polysaccharides in relation to animal nutrition. J. Dairy Sci. 74, 3583-3597.

Volpe, J.J., Vagelos, P.R., 1973. Saturated fatty acid biosynthesis and its regulation. Ann. Rev. Biochem. 42, 21-60. 